\title{
The Home Front: Norman Mailer's The Armies of the Night
}

\author{
O Front interno: Os Exércitos da Noite, de Norman \\ Mailer
}

\section{La Frente Interna: Los Ejércitos de La Noche, de Norman} Mailer

iD Luiz Carlos Moreira da Rocha

Professor Visitante na Universidade federal de Juiz de Fora (UFJF), Juiz de Fora, Minas Gerais, Brasil.

E-mail: luizcarlosmoreira@visitante.ufjf.br

\begin{abstract}
This paper aims to analyze the novel The Armies of the Night, by Norman Mailer, as a record of a march on the Pentagon held on October 1967 in a great protest against the Vietnam War. But, before approaching the novel itself, it is important to present some social and historical data in order to contextualize Mailer's narrative within the historical frame. It is relevant to stress that some facts quoted in the beginning of this paper are cited in the novel.
\end{abstract}

Keywords: America. Pentagon. Narrative. Vietnam. War.

Resumo: Este artigo tem por fim analisar o romance Os Exércitos da Noite (The Armies of the Night), de Norman Mailer, como um registro da marcha sobre o Pentágono ocorrida em outubro de 1967 em um grande protesto contra a Guerra do Vietnã. Porém, antes de abordar o romance em si, é importante apresentar alguns dados históricos e sociais de forma a contextualizar esta narrativa de Mailer dentro da moldura histórica. É relevante afirmar também que alguns fatos citados no início deste artigo são citados no romance.

Palavras-chave: America. Pentágono. Narrativa. Vietnã. Guerra. 
Resumen: Este artículo visa analizar Los Ejércitos de La Noche (The Armies of the Night), de Norman Mailer, como un récord histórico de la marcha sobre el Pentágono ocurrida en octubre de 1967 en una marcha en protesta cuentra la guerra en Vietnam. Pero, antes de abordar la novela adecuadamente, és importante presentar algunas informaciones históricas y sociales de forma que se possa contextualizar esta narrativa de Mailer dentro del marco histórico. És relevante también asegurar que algunos de los echos mencionados en el principio de este artículo son también mencionados en la novela.

Palabras-clave: Estados Unidos. Pentágono. Narrativa. Vietnam. Guerra.

The truth is on the march, nothing can stop it now. Émile Zola

Submissão em 07 de maio de 2021.

Aceito em 17 de setembro de 2021.

Publicado em 08 de dezembro de 2021. 
Seizing the opportunity that Postmodernism brought history back to the literary arena, Norman Mailer published The Armies of the Night in 1968. This novel is centered on the march on the Pentagon held on October 1967. However, it is necessary to provide some historical information as an introduction to the following study of The Armies of the Night, taking into account that some events quoted in the preamble are mentioned in the novel. This return of history to the contents of fictional and non-fictional narratives is a clear example of the interdisciplinary interaction between literature and history.

Looking back in historical perspective, January 14, 1967 recorded the first remarkable demonstration against President Johnson's policy for Vietnam. According to official estimations, from 20,000 to 30,000 people united in an antiwar protest in Golden Gate Park in San Francisco near Haight-Ashbury, the hippie sanctuary in California.

In the beginning the protests did not attract too many people because most of the Americans supported President Johnson's policy for Vietnam. However, as the war was turning harsher, adding to the internal social conflicts in American society, the manifestations against Johnson's policy grew all over the United States. After the antiwar demonstration in San Francisco mentioned above, other protests followed. In February, M.I.T.'s linguist Noam Chomsky published an article in The New York Times entitled "The Responsibility of Intellectuals", in which thousands of signatures of Professors and intellectuals were attached. In the text, Chomsky quotes another article written twenty years before by Dwight MacDonald, in which the author questioned the responsibility of the German and Japanese peoples in the atrocities committed by their governments in their names during the Second World War.

For the same reason, Chomsky argues in his article the responsibility of Americans and British for the nuclear destruction of Hiroshima and Nagasaki in an effort to update the question. Chomsky underscores the responsibility of the Americans in the invasion of Vietnam and on the attacks against that country. 
Chomsky explains how the same argument of the Communist advance in Asia and the Middle East has been used to justify imperialist aggressions everywhere. Moreover, there were the lies told by the American authorities to the national press as Arthur Schlesinger, the former President Kennedy's special assistant, did, using the argument of "national interest". Mr. Schlesinger remarked that the Vietminh would not negotiate while they thought they could win the war. Yet there was enough evidence that both North Vietnam and the Soviet Union wanted to set up negotiations before the beginning of the raids the Johnson administration ordered against North Vietnam.

On the one hand, the impact of "The Responsibility of Intellectuals" had been restricted to the academic community and intelligentsia by and large. On the other hand, 1967 registered a lot of other events that caused great impact on American society. According to John Bowman (1989, p. 103), "on March 17, The Reverend Martin Luther King Jr. leads a march of 5,000 anti-war demonstrators in Chicago". Indeed, King used the speeches he made during the Civil Rights campaign to stress his position in favor of the labor strike in Memphis and against the American war in Vietnam. As New York City was always the thermometer of American life, the city was the stage for one of the greatest demonstrations against the Vietnam War on 15 April, when 400,000 marched from Central Park to the United Nations Square. On that occasion, Dr. Benjamin Spock, Dr. Martin Luther King Jr., James Bevel, and Jan Berry Crumb, among other important personalities, were present.

Washington also witnessed some marches against the war. On May 30, the movement "Vietnam Veterans Against the War" was founded in the capital of the nation. While all these manifestations were happening, the polls showed a decline in the support of the Johnson administration's policy for Vietnam. According to Gallup, 52\% of the Americans disagreed the way the war had been administrated. By the end of the "Summer of Love", the protests were becoming real headaches for President Johnson who started to face opposition even in his own Democratic Party. As 
the electoral season was approaching, some important voices of the Democratic Party like Bobby Kennedy, Eugene McCarthy and George McGovern raised their voices against the Vietnam War and the way Johnson was managing the American participation in the conflict.

Given the racial and other social tensions in American cities, 1967 was also the year when many riots broke out from Newark to Los Angeles, from Detroit to Birmingham and the Summer of Love became the Summer of Unrest. Two important events which happened in October would have a remarkable impact on the recent history of the United States. First, Draft Week when thousands of young men returned their draft cards in all parts of the nation and caused one of the most important clashes recorded in Oakland, California. The other event, which draw the attention of the country and of the world, was the march on the Pentagon held from 21 to 23 October.

The estimations on how many people attended the march vary depending on the source. Some newspapers reported that at least 30,000 people gathered at the Lincoln Memorial; some others said that it was a crowd of 100,000 people. The march included many important activists and intellectuals like Abbie Hoffman, Jerry Rubin, Dwight MacDonald, Noam Chomsky, the poet Robert Lowell and the novelist Norman Mailer who documented the march, the arrests, and the events in a memorable non-fiction novel called The Armies of the Night.

Mailer was regarded by Malcolm Bradbury (1994, p. 197) as "the indicator of cultural change" and this perception is clearly expressed in his contributions to the changes in literary aesthetics and social panorama, emphatically in the mood of the American people related to the war in Vietnam. From the literary point of view, The Armies of the Night is a product not only of Mailer's inventiveness but of the cultural changes of 1960s America that led writers to look for new forms of expression. Following the work of Truman Capote, Tom Wolfe and others, Mailer uses a kind of language that characterizes the new literary genre called New Journalism, which 
is a style or a new way of writing in vogue during the 1960s and 1970 s and whose main feature is the mixture of journalism with literary technique. Tom Wolfe, Truman Capote, Norman Mailer, Hunther Thompson, Joan Didion and Robert Christgau are its most important adepts.

As Mailer was always concerned about the development of American political and social issues, he attempted to present in his 1968 novel a personal view of the historical event that was the march on the Pentagon in October of 1967, in which he, according to Bradbury and Ruland (1991, p. 382) "confronted the way realities are constructed by questioning the basic relation of historical actuality and fiction".

The mixture of literary genres aims to provide a view of history devoid of the scientific methodology that permeates historical data. In fact, a record of the multifaceted details about the historical event could only be made by a novelist like Mailer, who created a narrative in which he is both a character and a narrator at the same time. If we take into consideration the needs of historiography conceived in accordance with a method that proposes objectivity, controlled predictions, etc., few historians and social scientists could give a record of those events with the richness of details and accuracy in the voices of the non-central characters as a writer like Norman Mailer. I justify this argument based upon the fact that a writer has more freedom to express his points of view as he/she has not to follow the rigor of the scientific method.

Mailer is one of the first writers of our time to manage the problem of historical narrative. If the historical event, like the march on the Pentagon, could be neither subject to experimental control nor observed in retrospect, it could be transformed into a narrative through the process that Hayden White called "emplotment" (ed.1978, p. 399), which was exactly what Mailer did. The incompleteness and provisional nature of the event became the raw material through which Mailer structured the non-fictional novel that, in turn, became the most important reference of that historical event, overwhelming even the official historical accounts. 
The Armies of the Night was written to deconstruct the dichotomy form and content from a hybrid perspective, which interweaves historical event, journalistic reportage and literary techniques. Its aim is to provide a unique view of the march on the Pentagon and the protest against the American war in Vietnam that took place in Washington and Virginia in October of 1967.

Besides the experimentalism in the literary field, it is important to stress the discredit the intelligentsia attributed to the official sources of information. Mailer, therefore, wentto the demonstration on the Vietnam War as a participant, witness, and narrator of that remarkable historical event. The march on the Pentagon turned into material for the narrative Mailer wrote, alternating the first and third persons in order to shape and contrast the conventions that guided the historical text as well as the literary composition. Another meaningful aspect of Mailer's novel that contrasts with the official historical narrative is that the latter is usually made out of chronicles, while The Armies of the Night may be regarded as a chronicle of the event.

Concisely, the content of The Armies of the Night relates the preparation for the march; its beginning shows the writer Mitchell Goodman calling on Mailer, and the dialogue between the writer and the poet Robert Lowell. The literary critic Dwight MacDonald and Ed de Grazzia, a leading Professor of Law at Yeshiva University in Manhattan, join them. The first day of protest is marked by the burning of draft cards before the Department of Justice. The second day, a Saturday, is the time when the march is held and many arrests are made, including the one of Mailer himself. In jail, Mailer seizes the opportunity to make some reflections on the event, the history of the United States, and the Vietnam War. On the third day, Mailer and many other demonstrators are released.

The Armies of the Night is divided into two parts. The first, "History as Novel: The Steps on the Pentagon" was made up as a diary teemed with digressions on the author's biography and his view of capitalist America. The narrative culminates with his impressions of the march. The content of the text attempts to 
present history as fiction and brings to the surface the question of the objectivity and impartiality of the historical account. In accordance with the historiographic metafiction, Mailer inserts at the heart of the narrative a character that is not central to the historical event narrated, i.e., he himself.

Mailer, the narrator, looks at the other characters with a mixture of surprise and strangeness. For the other members of the march, he is also a character, if we take into account his unfamiliar look when he sees the young men burning their draft cards, a scene already mentioned, but that shocks Mailer (ed. 1994, p. 10). In fact, no one but Goodman and Lowell could be regarded as his peers. Even Robert Lowell seems to be a little bit odd as his mode of representing reality differs from Mailer's in form.

Mailer wrote Book One as if it were a diary, another literary traditional form in the English language, to portray the march and include material on his own life. When Mailer introduces his text as history as fiction, he is contesting the objectivity of the historiographic accounts and showing us that the fact, historical or common, can only be apprehended through the lens of subjectivity. Its narration is, therefore, the view of the one who narrates the fact. A view of a historical fact in a perspective of a narrator, who is not a central character in the event, constitutes a metafictional enterprise with the center of the narrative occupied by a marginal character.

The novel opens with an extract from an article published in Time magazine, and it works as an announcement that the postmodern strategy of using the intertextual process will be paramount in the narrative. Besides, pieces of articles from magazines and newspapers are part of the tactics Mailer uses to question the objectivity of the historical records. The opening also suggests that literature is the most suitable vehicle to portray the historical events of our time.

The preparatory actions for the march include the ritual of burning the draft cards. Mailer, the narrator, expresses the anxiety and doubt of Mailer, the character, who is supposed to convince 
the young men to do what he did not know if he would do in case of being in their place (ed. 1994, p. 10). The contradiction of a postmodern citizen and writer manifests in the dependence he has in relation to the object that has been contested, i.e. the war in Vietnam. Anyway, the act of burning the draft cards is not enough to destroy the causes of the cards, which turns the action into a symbol of resistance rather than an act that could force the authorities to stop sending the cards to American youth.

Mailer believed that the best way he could oppose the war in Vietnam was through literature. He points out (ed. 1994, p. 9): “One's own literary work was the only answer to the war in Vietnam". And literary tradition is at the heart of his protest, as we can see through intertextual process in order to portray his political message. As a means to justify his literary "weapon" against the war, he searched in romantic poetry the appropriate argument to make his deal, in other words, Edward Litton's verse "the pen is mightier than the sword" (ed. 1994, p. 22), from the play Richelieu; or The Conspiracy is the motto he chose to carry his message. Here, Mailer's discursive operation is a means to enter another sphere, the poetic one, and to return to his updated world, which is not the one of reality but the world of textuality through which he constructs his opposition to both realities, the internal world represented by the American capitalist system and its institutions that surround Mailer's life and his fellow Americans, and the other, external but linked to the former, which is stood for the Vietnam War.

"Mailer", the character, goes to The Ambassador Theater leading his internal conflicts. It is decided that he would be speaker and master of ceremonies, but he feels that "the two would conflict, but interestingly" (ed. 1994, p. 29). As the history of protests in America goes back to the Civil War, the one at the Ambassador Theatre looked like a pop show in which the stars of Rock Music and Literature would held their performances for a young audience. In spite of the 1960s America, with its hippie counterculture, being a form of postmodern transcendentalism, Mailer's mug of Bourbon and the hippies' LSD and marijuana would shock Emerson and 
Thoreau, the fathers of protest in American culture, and whose ghosts were brought to the stage by Mailer himself who was "illumined by these first stages of Emersonian transcendence..." (1994, p. 32).

Some years before, William Faulkner was asked by a reporter why he had become a writer and he answered that all novelists are failed poets. True or not, Mailer manifests his jealousy of the poet Robert Lowell given the poet's performance in the theatre that stole the scene. Independently of being jealous or not, the fact is that poetry and happening form a perfect couple. This is the reason why Dwight Macdonald recites a poem, The White Man's Burden, by Rudyard Kipling (1994, p. 42-3), a poem written for another context but which fits the reflections on the American imperialist aggression on Vietnam. At the end of the meeting, Mailer reads a passage of his then new novel Why Are We in Vietnam? that would be published inside The Armies of the Night and it would be a construction of a mise-en-abyme, i.e., a novel within a novel. But he avoids being redundant and prefers to end his speech with a "See you on Saturday!" (1994, p. 51), which is answered with applause by the audience.

On Saturday during the march on the Pentagon, Mailer regards it as an ambiguous event, whose "... essential value or absurdity may not be established for ten or twenty years, or indeed ever" (1994, p. 53). The ambiguity he observes is based on a divided society in relation to its own principles and to the involvement of the United States in the Vietnam War. Thomas Burns, in an analysis of The Armies of the Night (2005, p. 260), argues that

Mailer summarizes in three pages (1968: 193-196) the political and strategic arguments of the Vietnam war's supporters (the "Hawks") and their opponents (the "doves"), only to conclude that, while on the face of it the Doves' arguments are stronger, power is never destroyed by superior argument. 
Mailer's reasoning shows how one of the greatest democracies in the world uses some techniques of espionage which are much more peculiar to third world dictatorships. It is known that C.I.A. and F.B.I. infiltrated a lot of agents in the crowd that attended the march in order to take photos of the subversives, as Mailer, the narrator, points out on page 69 . His fierce criticism on the American foreign policy is the tone of his speech before the Department of Justice: "If what the United States is doing in Vietnam is right, what is there left to be called wrong?" (1994, p. 71).

During the march, slogans and songs of protests are intoned by the crowd. Butasnormally happensinAmericansocial manifestations, the issues related to race come to surface. An African-American young man raises a placard written "NO VIETNAMESE EVER CALLED ME A NIGGER" (MAILER, 1994, p. 115), and it is not a coincidence that that kind of placard is being raised exactly in a manifestation held in the Southern territory of the United States, considering that Virginia, like the rest of the Old South, was always regarded as a bastion of racism. The boldness and creativity of the young black man draws Mailer's attention and he registers the episode that allows us to reflect not only on the racial problems of America but also on the fact that many African-Americans are sent to Vietnam under difficult circumstances to fight the enemies of their internal enemies.

Still in the middle of the march, the oriental mantras and antiwar slogans alternate with the speeches and songs performed on the way to the Pentagon. However, one of the most expressive moments of the protest is taken by the poet Robert Lowell, who seizes the opportunity to recite poems (1994, p. 124), which allows Mailer to show all his ability as a "literary critic". Mailer's quotation on Lowell's poetry constitute a metafictional or postmodern operation in which the intertextual technique, the oral performance, and criticism are joined together to represent what can be, perhaps, one of the most picturesque moments of the demonstration. In Mailer's own words (ed. 1994, p. 125): 
Lowell's poetry gave one the sense of living in a well, the echoes were deep, and sound was finally lost in moss on stone; down there the light had the light of velvet, and the ripples were imperceptible. But one lay on one's back in this well, looking up at the sky, and the stars were determinedly there at night, fixed points of reference; nothing in the poems ever permitted you to turn on your face and try to look down into the depths of the well, it was enough you were in the well-now, look up! The world dazzled with its detail.

The American political and military authorities, from the Truman to Johnson administrations, had defended a policy of containment of Communism everywhere, but starting to blockade its advance in Asia. Nevertheless, the reach of Mailer's thought expressed in The Armies of the Night postulates an opposite direction. The former Secretary of State, Henry Kissinger, commenting on Mailer's claim for a complete withdrawal of the U.S. forces from Vietnam, quotes a passage from Mailer's novel (1994, p. 710 on 1968, p. 187):

If the Communism prevailed in Asia...Divisions, schisms and sects would appear...Therefore, to leave Asia would be precisely to gain the balance of power...For the more Communism expanded, the more monumental would become its problems, the more flaccid its preoccupations with world conquest. In the expansion of Communism was its own containment. The only force which could ever defeat Communism, was Communism itself.

Kissinger, who has no trace of a literary critic, comments in his Diplomacy (1994, p. 710) that 
In the sequence, Kissinger attests that Mailer's paradox is outlined in the idea that the collapse of the Communist regime would come with its expansionism, a policy that would expose its weakness and that America's position should be "an abstention from resistance to communism" (1994, p. 710). Kissinger believed that Mailer was wrong but history proved otherwise; in other words, the writer was correct as the advance of Soviet Communism to the Balkans, the Caucasian areas, and Afghanistan turned the artificial Soviet confederacy into a weak empire. In fact, the former U.S.S.R. collapsed without a single bullet being shot by the U.S. Army or its allies; the Soviet Union collapsed from within and it did not survive the wave of changes that swept Eastern Europe in the late 1980s and early 1990 s.

The title of the second part "The Novel as History: The Battle of the Pentagon" addresses Mailer's effort to aim at objectivity in the historical record. At its core, this part of the novel records the ideological conflict which stands at the two sides of the struggle involved in the protests against the Vietnam War. If, on the one side, the liberals, represented by the lords of the war and by the mainstream media owners, fight against the radicals, who opposed the war; on the other side, the narrative brings, equally, the internal conflict on the left side of the political spectrum, i.e., the old fight between the Old and the New Left comes to the front line.

The binary terms camouflage the fragments, the divisions in the two fields of the Left. Marxism is a label which shelters a host of different readings and practices of that ideology and the new left is an umbrella that covers a lot of trends. To be precise, on the side of the Old Left, there are the guardians of Marxism with their polished, calculated, and articulated rhetoric. The New Left, in turn, shelters the social segments that emerged from the 1960s counterculture such as Hippies, Black Panthers, Feminists, Ecologists, among others. In that context, Norman Mailer, in tune with the historical moment he was living, turned this style into a priority in relation to the content that shapes the happenings that overwhelms the premises of the Old Left. 
The style Mailer uses in The Armies of the Night allows him, as a character and narrator, to circulate in the spaces that belong to the fictional character and the journalist who takes the advantage of his presence in loco to produce his report. For having done so, both the character and the narrator incarnated in Mailer use the literary technique of scene by scene construction, detailed incidents, and dialogues recorded, which feature the genre New Journalism. Moreover, it is important to underscore that Mailer's style, with its blend of journalist account, historical data, and literary narrative, alternates the first and third persons' view to construct a narrative based on the movement of coming and going, which results in an inside view full of passion and an outside one supposedly dispassionate.

There is another important point, in terms of literary aesthetics, that must be emphasized. Patricia Waugh argues in Metafiction (1984, p. 65-66) that

\begin{abstract}
Although the notion of the 'high art' remains, therefore, it becomes a dynamic category which constantly redefines itself through the popular and the non-literary. Metafiction explicitly and self-consciously performs these functions, for it seeks to avoid a radical break with previous literary traditions.
\end{abstract}

Like a Structuralism's tenet that states there is a readjustment in the linguistic system any time that a new item is included or excluded, the same applies to metafiction, which does not break with the past and its forms of representation but reorganizes them from a transformation through parody and irony. This operation is one more postmodern enterprise of The Armies of the Night as it neither obliterates past narratives nor the popular forms, but it dialogues with them parodying their contents.

The hybridism of The Armies of the Night goes beyond the amalgam of literary genres and the usage of the intertextual process. In reality, the style and the form of Mailer's novel 
resemble the descriptions produced by anthropologists when they are picturing the culture of a specific people or nation. It is exactly what Mailer does when he goes from New York City to the capital of the United States to take part in the march on the Pentagon; he observes the protesters, talks to the folks, collects data, and produces his narrative.

Style seems to be an inappropriate word to characterize a novel made up of a mixture of genres, i.e., poetry, journalism, diary, missive, chronicle, musical lyrics and the novel itself. It is a postmodern narrative that challenges its own status as novel and that uses and abuses the conventions it challenges. In spite of being based on a historical event, it is important to ponder that it does not mirror the fact but it is a discourse Mailer constructs to purvey a view of the historical event that are the demonstrations and rallies on the Vietnam War in those days of October 1967.

Anticipating some premises which would be established by the theory called New History and advocated by Hayden White in the 1970s, Mailer reflects how the historical realities and historical accounts are discursive constructions. Mailer's narrative points towards the insufficiency of the journalistic account and of the historical text. This conclusion made him to turn the literary construct into the modus operandi of the historical record. The Armies of the Night brings self-reflexivity as a discursive mechanism through which the provisional and uncertainty feature the version of the historical fact. It also stresses the potentials and the limits that characterize the writing of the past.

As a non-fictional novel, The Armies of the Night shares some points with a historiographic metafiction due to the fact that neither trust in the capacity of historiography to cover the realities of human experience or to provide a version of reality that can be sustained. Mailer's novel brings in its two parts moments of reflection by the narrator who addresses the readers about the conventions and narrative tools used by both novelists and historians. The self-reflexivity of the novel, already stressed as a metafictional characteristic, points straight to the historical 
The Home Front: Norman Mailer's The Armies of the Night Luiz Carlos Moreira da Rocha

reference of the narrative. Given this, Hutcheon observes (1988, p. 117) that

Like many postmodern novels, this provision-ality and uncertainty (and the willful and overt constructing of meaning too) do not "cast doubt upon their seriousness" (Butler 1980, 131), but rather define the new postmodern seriousness that acknowledges the limits and powers of "reporting" or writing of the past, recent or remote.

The Armies of the Night is a title that addresses us to Mailer's army and like every army, Mailer's is composed of diversified people from all origins and features. The author and the narrator meet each other in the way that they describe the leaders of the march. Dr. Spock, for example, is a portrait of Mailer's conflict as Dr. Spock wrote a baby book that is a reference for Mailer's first three wives. Noam Chomsky, another antiwar activist, attracted Mailer's attention given his intelligence and prominence as a linguist of M.I.T. The masses of demonstrators are represented by groups like hippies, blacks, feminists, and others. The psychology of the characters differs from the profiles normally found in the novels, and it is another feature that distinguishes Mailer's narrative from the others of the American literary tradition.

Yet it was Hutcheon (1988, p. 117) who figures out the metafictional strategy used by Mailer to build the form and content of his non-fictional novel. She writes:

Norman Mailer's The Armies of the Night is subtitled History as a Novel, the Novel as History. In each of the two parts of the book there is a moment in which the narrator addresses the readers on the conventions and devices used by novelist $(1968,152)$ and historians (245). 
And speaking of historians, Hayden White compares, in The Historical Text as Literary Artifact, the "reemplotment" of the historical data with a situation of a patient who must "reemplot" his own history in something meaningful "for the economy of the whole set of events that make up his life" (WHITE, 1978, p. 399). The operation Mailer undertakes is similar, i.e., he transforms his own experience on the march into a narrative full of meaning not only for himself and those who take part in the event but for all the readers and for the history of American literature and to the history of the United States of America as well.

The first person narrative must be stressed as the means Mailer finds to show that historical record from that point of view is rather limited or partial. Another reason why he chose the first person narrative lies in the fact that he, as participant and witness of the march, did not have a complete view of the event. On the contrary, from his position, he neither could see most of the participants nor their attitudes. Consequently, what he wrote is a history made up by the others, and, consequently, the amount of details is a kind of patchwork kilt of the whole event that he weaves.

Book Two depicts Mailer's creativity in reporting the facts he had not witnessed. To do so, he uses some intertextual strategies from the mainstream media, such as the television channel CBS and the newspaper The Washington Post. In this section, we can see how Mailer works journalism as a literary genre presenting a step by step coverage of that weekend. The planning of the march was organized several months before by moderate people like the pacifist David Dellinger, editor of Liberation, and the radical activist Jerry Rubin. In this section, Mailer shows how the Johnson administration managed the demonstration in order to avoid the riots in Washington that could turn into a disaster for the government with international repercussions.

Starting with the organization of the event, Book Two discusses the division between the liberals and the radicals or the Doves versus the Hawks, which symbolizes the split in American society. To what concerns the American war in Vietnam, the position of 
the radicals is more "aggressive" in a sense that they opposed the conflict and have more reasons to raise their flags and brag in the streets. The liberals, in turn, have power and money to afford their position.

Yet these two sides joined their efforts to organize the march as it needed a great number of participants to achieve the goal of providing repercussion to the media for the event and money to pay the costs of a happening of that magnitude. This contrast is symbolized by Dellinger and Rubin who personify the conflict in the left. They also have the need to oppose the establishment and its support for the war in Vietnam.

According to the narrator (1994, p. 267), "the real climax on the steps of the Pentagon was yet to occur". If there is an internal conflict among the protestors, which is labeled as the Old Left versus the New Left, there is also an external conflict between the demonstrators and the security forces. The remaining protestors and journalists face the soldiers and tear gas and clubs that were used against the Minorities, especially women and AfricanAmericans, that had an important role in the conflict as shown in the next quotations (1994, p. 269): “The girls were now taunting the soldiers on the line" and "Earlier in the day, a couple of Negro demonstrators were reported to have taunted a Negro soldier...". Following the confrontation, arrests were made.

Life in prison is reported in the middle part of the novel. The monotony and the suspension of time perception plus the conversations Mailer strikes up with his cellmates are at stake. Here, it is important to underline the boldness of the writer, which allows him to be imprisoned while many other illustrious people would avoid being jailed. Once in the cell, he shares his experiences with a lot of young people, most hippies and students. The aim of being arrested is to provide the event with national and international repercussion and to force the American authorities to realize the mistake of waging war on Vietnam. When asked by a reporter why he had been arrested, Mailer answers (1994, p. 137-8): 
"I was arrested for transgressing a police line." (Of course, he was misquoted," said Mailer's sister later. "He wouldn't use a word like transgress." She did not anticipate the solemnity men bring to these matters.) "I am guilty," Mailer went on. "It was done as an act of protest to the war in Vietnam." "Are you hurt in any way?" asked the reporter. "No. The arrest was correct".

All of these conjectures allow me to say a word on the role of the media in the record of the historical events of that time. If in previous centuries, the official chronicles and the annals constituted the sources or bases for the writing of history, from the twenty century onwards, the role of media became paramount. The same criticism imputed to the objectivity of the historians may be extended to the media, being it visual or written. In the 1960s America, for example, aesthetic politics acquired new shape. Thus, I agree with Tom Burns' arguments (2007/9, p. 272) when he stresses that "Mailer is at least being true to the new (i.e. the Sixties) form of aesthetic politics he himself had described, where style is more important than substance, and the "happening" replaces the Old Left logic".

In After the Great Divide (1986, p. 191), Andreas Huyssen points out that

The historical constellation in which the Postmodernism of the 1960s played itself out (from the Bay of Pigs and the civil rights movement to the campus revolts, the anti-war movement and the counter-culture) makes this avant-garde specifically American, even where its vocabulary of aesthetic forms and techniques was not radically new.

So, it is appropriate and opportune to point out that all these features are presented in Mailer's The Armies of the Night, a nonfictional novel that is an x-ray of the cultural manifestations that took place in the 1960s America and whose legacy is ours to share. 
The Home Front: Norman Mailer's The Armies of the Night Luiz Carlos Moreira da Rocha

At the same time that the postmodern novels, like The Armies of the Night, depend on the historical event, the opposite is also true, i.e., the postmodern literature brings history back to the contents of fictional and non-fictional narratives. Consequently, we can conclude that the divorce between these two humanistic areas did not prevail. It is not only a criticism against the modernist avant-garde, which obliterated the past, but a certainty that the relationship between literature and history is a double-edged road in which the historical events provide raw material for the literary contents and literature turns into an appropriate vehicle to record the historical fact.

All in all, The Armies of the Night is much more than a nonfictional novel that embodies a new literary genre, New Journalism. It is also more than a historical record of an important event of the recent American history. It is not only one more landmark in the remarkable literary career of Norman Mailer. It is, indeed, a literary and historical monument whose legacy will demand studies from the current and future generations.

\section{References}

BOWMAN, John S. (ed.). The Vietnam War - Day By Day. Hong Kong: Magna Books, 1989.

BRADBURY, Malcolm \& RULAND, Richard. From Puritanism to

Postmodernism. New York: Penguin, 1991.

BRADBURY, Malcolm. The Modern American Novel. New York: Penguin, 1994.

BURNS, Thomas L. "Radical Politics and Multiple Identities in Protesting the Vietnam War: Norman Mailer and The Non-Fictional Novel" Estudos Anglo-Americanos. n. 31-33. p. 257-274. 2007-2009.

CHOMSKY, Noam. The Responsibility of Intellectuals - The New York Review of Books. Available on www.chomsky.info.com. Access on 03 May 2021. 
The Home Front: Norman Mailer's The Armies of the Night Luiz Carlos Moreira da Rocha

HUTCHEON, Linda. Poetics of Postmodernism - History, Theory, Fiction. New York: Routledge, 1996.

HUYSSEN, Andreas. After The Great Divide. Bloomington and Indianapolis: Indiana U.P., 1986.

KISSINGER, Henry. Diplomacy. New York/London/Toronto/Sydney: Simon \& Schuster, 1994.

MAILER, Norman. The Armies of the Night. New York: A Plume Book, 1994.

WAUGH, Patricia. Metafiction. London and New York: Routledge, 1996.

WHITE, Hayden. The Historical Text as Literary Artifact. In :WHITE, Hayden. Tropics of Discourse: Essays in Cultural Criticism. 2nd edition. Baltimore: John Hopkins University Press, 1978. p. 394-407. 